\title{
Arbuscular mycorrhizal symbiosis can mitigate the negative effects of night warming on physiological traits of Medicago truncatula $\mathbf{L}$
}

\author{
Yajun Hu • Songlin Wu • Yuqing Sun • Tao Li • \\ Xin Zhang • Caiyan Chen • Ge Lin • Baodong Chen
}

Received: 9 April 2014 / Accepted: 7 July 2014 / Published online: 19 July 2014

(C) Springer-Verlag Berlin Heidelberg 2014

\begin{abstract}
Elevated night temperature, one of the main climate warming scenarios, can have profound effects on plant growth and metabolism. However, little attention has been paid to the potential role of mycorrhizal associations in plant responses to night warming, although it is well known that symbiotic fungi can protect host plants against various environmental stresses. In the present study, physiological traits of Medicago truncatula L. in association with the arbuscular mycorrhizal (AM) fungus Rhizophagus irregularis were investigated under simulated night warming. A constant increase in night temperature of $1.53{ }^{\circ} \mathrm{C}$ significantly reduced plant shoot and root biomass, flower and seed number, leaf sugar concentration, and shoot $\mathrm{Zn}$ and root $\mathrm{P}$ concentrations. However, the AM association essentially mitigated these negative effects of night warming by improving plant growth, especially through increased root biomass, root to shoot ratio, and shoot $\mathrm{Zn}$ and root $\mathrm{P}$ concentrations. A significant interaction was observed between $R$. irregularis inoculation and night warming in influencing both root sucrose concentration and expression of sucrose synthase (SusS) genes, suggesting that AM symbiosis and increased night temperature jointly regulated plant sugar metabolism. Night warming stimulated AM fungal colonization but did not influence arbuscule abundance, symbiosis-related plant or fungal gene expression, or growth of extraradical mycelium, indicating little effect of night warming on the development or functioning of AM
\end{abstract}

$\mathrm{Y} . \mathrm{Hu} \cdot \mathrm{S} . \mathrm{Wu} \cdot \mathrm{Y} . \mathrm{Sun} \cdot \mathrm{T}$. Li $\cdot$ X. Zhang $\cdot$ G. Lin $\cdot$ B. Chen $(\triangle)$ State Key Laboratory of Urban and Regional Ecology, Research Center for Eco-Environmental Sciences, Chinese Academy of Sciences, Beijing 100085, China

e-mail: bdchen@rcees.ac.cn

C. Chen

Institute of Subtropical Agriculture, Chinese Academy of Sciences,

Changsha 410125, China symbiosis. These findings highlight the importance of mycorrhizal symbiosis in assisting plant resilience to climate warming.

Keywords Arbuscular mycorrhiza $\cdot$ Night warming · Medicago truncatula $\cdot$ Sugar metabolism $\cdot$ Symbiosis-related genes $\cdot$ Zinc

\section{Introduction}

Worldwide climate records show that global surface temperature has increased $0.74{ }^{\circ} \mathrm{C}$ from 1906 to 2005 , and it is predicted to increase continually during this century (Pachauri and Reisinger 2007). Global warming has received much attention because of its profound influence on both productivity and stability of natural ecosystems (Alward et al. 1999; Luo 2007; Bond-Lamberty and Thomson 2010) and also on crop yield in agricultural ecosystems (Peng et al. 2004). Different artificial warming scenarios, such as day, night, or diurnal warming, have shown differential effects on plant physiological traits and ecosystem productivity. For example, Bai et al. (2012) observed that day warming can, but night warming cannot, prolong root lifespan. Also, Wan et al. (2009) reported that day warming significantly decreased, while night warming increased, gross ecosystem productivity in the semiarid temperate steppe in northern China.

The night warming scenario may have a more universal impact since a more significant increase in night temperature than in day temperature has been observed worldwide over the past 50 years (Pachauri and Reisinger 2007). Night warming can have multiple effects on plant physiology. Earlier studies reported that elevated night temperature had deleterious effects on pollen viability and pollen tube germination, eventually leading to grain weight loss (Hedhly et al. 2009; Grant et al. 2011). Night warming can also affect plant 
photosynthesis and respiration. McDonald and Paulsen (1997) reported that photosynthetic rates of cowpea were lower at day/night temperatures of $30 / 25{ }^{\circ} \mathrm{C}$ than at $30 / 15^{\circ} \mathrm{C}$, while Turnbull et al. (2002) reported a significant increase in the photosynthetic capacity of Populus deltoides under night warming. In addition to these effects on photosynthesis, night warming typically stimulates the dark respiration of a plant and leads to depletion of carbohydrates (Wan et al. 2009).

Many studies have investigated how night warming directly affects plants. However, few studies have considered the potential influence of night warming on the development and functionality of symbiotic microorganisms associated with plants. Ubiquitous arbuscular mycorrhizal (AM) symbioses (Smith and Read 2008) promote plant uptake of mineral nutrients (Smith and Read 2008) and water (Augé 2001; Li et al. 2013), upregulate photosynthesis (Kaschuk, et al. 2009), and enhance plant resistance to various biotic and abiotic stresses (Pozo and Azcòn-Aguilar 2007). Field investigations and greenhouse experiments under simulated climate warming have demonstrated that temperature increases potentially have positive effects on AM symbiosis (Rillig et al. 2002; $\mathrm{Hu}$ et al. 2013). A temperature increase from 15 to $20{ }^{\circ} \mathrm{C}$ in the growth medium directly stimulated hyphal elongation for one AM fungal species (Tommerup 1983). However, as AM fungal growth totally relies on carbohydrates from the host plant and night warming can stimulate plant dark respiration, leading to reduction in plant carbohydrate accumulation (Turnbull et al. 2002; Wan et al. 2009), it is predictable that night warming could potentially suppress development of the AM symbiosis due to a decreased available carbohydrate pool in the host plant.

Previous studies have reported significant differences in root uptake of mineral nutrients under different root-zone temperatures (Tindall et al. 1990; Hood and Mills 1994), suggesting that plant mineral nutrient acquisition is also sensitive to temperature change. Considering the primary contribution of AM fungi in providing mineral nutrients such as phosphorus and trace elements to their host plants (Smith and Read 2008), it is of interest to know whether AM fungi and night warming interactively influence plant nutrient acquisition.

Therefore the present study aimed to test the hypothesis that night warming could negatively affect plant growth and certain plant physiological traits, while plant responses to night warming could be substantially modified by AM symbiosis. A pot experiment was designed to comprehensively assess the influence of night warming on plant growth and development, and the involvement of AM association in plant response to night warming. Key physiological traits of the host plant Medicago truncatula L. was investigated: biomass, flower, and seed production, mineral nutrient acquisition, sugar assimilation, and expression of sucrose synthase family genes (SucS). The three macronutrients, phosphorus (P), potassium $(\mathrm{K})$, and calcium $(\mathrm{Ca})$, were examined based on their key roles in plant development, and also the micronutrient zinc $(\mathrm{Zn})$ considering that it is an integral component of many enzymes and $\mathrm{Zn}$ deficiency can result in plant physiological impairments and infertility. Furthermore, to gain insights into night warming effects on AM functional activity, we assessed mycorrhizal colonization, extraradical mycelium development and expression of symbiosis-related genes, such as MtPT4 and GiMST2 (Javot et al. 2007; Helber et al. 2011) which partake in the trade-off of carbon for phosphate between the symbiotic partners.

\section{Materials and methods}

Experimental materials

The cultivation system adopted was a compartmented microcosm. The two compartments of each microcosm $(13.5 \mathrm{~cm} \times$ $14 \mathrm{~cm} \times(7+7) \mathrm{cm}$, height $\times$ depth $\times$ width) were separated by a 37- $\mu$ m nylon mesh, which only allowed penetration by AM fungal hyphae but not by roots. One compartment was designated for plant growth (plant compartment, PC), while the other for development of extraradical mycelium only (hyphal compartment, HC).

The experimental soil, collected from Panggezhuang Village, Daxing District, Beijing, was a sandy loam with $\mathrm{pH}$ 8.53 (1:2.5 in water), $10.2 \mathrm{~g} \mathrm{~kg}^{-1}$ organic matter, and $5.90 \mathrm{mg} \mathrm{kg}^{-1}$ available phosphate (extracted with $0.5 \mathrm{~mol} \mathrm{~L}^{-1} \mathrm{NaHCO}_{3}$ ). Soil was passed through a 2-mm sieve, autoclaved $\left(121{ }^{\circ} \mathrm{C}, 60 \mathrm{~min}\right.$ on two consecutive days) and mixed with quartz sand $(0.3-0.5 \mathrm{~mm})$ at a ratio of $3: 1(v / v$, soil/sand).

Medicago truncatula cv. Jemalong A17 seeds were obtained from the Institute of Subtropical Agriculture, Chinese Academy of Sciences. Inoculum of the AM fungus Rhizophagus irregularis Błaszk, Wubet, Renker, and Buscot (recently renamed from Glomus intraradices Schenck and Smith by Schüßler and Walker 2010), isolate BGC AH01, was provided by the Beijing Academy of Agriculture and Forestry Sciences, and consisted of sand, spores, mycelia, and colonized root fragments.

Experimental design and plant growth conditions

There were a total of four treatments with four replicates each (16 microcosms): plants inoculated or not with $R$. irregularis, grown under ambient temperature or simulated night warming conditions. In inoculated treatments, $25 \mathrm{~g}$ of AM fungal inoculum (c.a. 1,500 spores) was carefully mixed into the growth medium of the $\mathrm{PC}$, while non-AM treatments received an equivalent amount of autoclaved AM inoculum. Seeds of M. truncatula were scarified in sulfuric acid for approximate 
10 min until black spots developed on the seed coat and then vernalized at $4{ }^{\circ} \mathrm{C}$ overnight. Seeds were germinated 3 days at $25{ }^{\circ} \mathrm{C}$ in the dark on damp filter paper in Petri plates, and then sown into the microcosm PCs in the glasshouse. After 1 week, seedlings were thinned to three per microcosm.

The night warming treatment was realized using overhead infrared radiators, which are widely used to simulate climate warming. This heating device is able to increase the plant canopy and soil temperature but does not affect other environmental parameters such as air moisture (Kimball 2005). Based on the field trial by Wan et al. (2009), four MRM-2408 infrared radiators (Kalglo Electronics, Bethlehem, Pennsylvania, USA) were suspended $1.8 \mathrm{~m}$ above microcosm replicates in the glasshouse. Heaters were timed to turn on from 21:00 to 07:00 hours, and radiation output was adjusted to $600 \mathrm{w}$ to generate a reasonable soil temperature increase. Soil temperature at the depth of $10 \mathrm{~cm}$ was recorded automatically every $30 \mathrm{~min}$ using Datalogger (TZS-6W Soil Temperature Measurement System, Top Instrument, Zhejiang, China), and a mean of 20 measurements between 21:00 and 07:00 hours was calculated to give the daily night temperature. Night soil temperature increased from 0.53 to $2.48{ }^{\circ} \mathrm{C}$ in the night warming treatment, with an average of $1.53{ }^{\circ} \mathrm{C}$ for the whole plant growth period compared to the ambient temperature control treatment. The soil surface temperature was only slightly higher (about $0.2{ }^{\circ} \mathrm{C}$ ) than at 10 -cm soil depth. Considering that heaters can also heat the plant canopy, leaf temperature was checked at intervals using a handheld infrared thermometer; this increased between 1.0 and $3.81{ }^{\circ} \mathrm{C}$ at different leaf positions across the plant growth period.

Plants were grown in a controlled environment greenhouse at $14 / 10 \mathrm{~h}$ and $25 / 20^{\circ} \mathrm{C}$ (light/dark). 500-1,100 $\mu \mathrm{mol} \mathrm{m}^{-2} \mathrm{~s}^{-1}$ photosynthetically active radiation (PAR) was provided by natural light and supplementary lights from high pressure sodium lamps. In total, 12 set of lighting lamps were installed in the greenhouse. The infrared radiators were installed between two lamps to avoid shading of plants during light periods. The four treatments were arranged in two groups, with one group (each corresponding to inoculated and uninoculated treatments) subjected to simulated night warming, and another under ambient temperature. The eight microcosms in the night warming treatment (two microcosms placed under each heater) and those under ambient temperature were randomized and regularly re-randomized during the experimental period, thus fitting a block design. To avoid negative effects of night warming on soil moisture, microcosms were watered daily to a soil water content of approximate $60 \%$ water holding capacity by weighing. At the $25^{\text {th }}$ and $40^{\text {th }}$ day after planting, each $\mathrm{PC}$ received $50-\mathrm{mL}$ nutrient solution containing $12.5-\mathrm{mg}$ P, $60-\mathrm{mg} \mathrm{K}$, and $45-\mathrm{mg} \mathrm{N}$ to support normal plant growth.
Plant harvest and chemical analysis

Plant shoots and roots were separately harvested at 58 days after planting and seeds were counted for determination of seed yields. Flower number, identified by fully opened petals, was recorded before harvest. Root samples were carefully washed with deionized water to remove adhering soil particles. Two sub-samples of plant leaves, shoots, and roots were prepared separately to determine the concentrations of soluble sugars and mineral nutrients. Dry weights were determined on one subsample to calculate the dry biomass of plants after oven-drying at $70{ }^{\circ} \mathrm{C}$ for $48 \mathrm{~h}$. For determination of mineral nutrients, dried plant samples were milled and digested in $\mathrm{HNO}_{3}$ using a microwaveaccelerated reaction system (Mars, CEM Corp.) and then measured by inductively coupled plasma atomic emission spectrometry (ICP-AES, Prodigy, Leeman Labs, USA). Soluble sugar contents (glucose, fructose and sucrose) were determined enzymatically using the K-SUFRG kit (Megazyme, Wicklow, lreland). In brief, fresh plant material (0.5-g leaves, 0.5 -g shoots, and 0.3 -g roots) was extracted using $80 \%$ ethanol for $1 \mathrm{~h}$ at $80{ }^{\circ} \mathrm{C}$. After centrifugation at $10,000 \times g$ for $2 \mathrm{~min}$, the supernatant was used for hexokinase (glucose), phosphoglucose isomerase (fructose), and invertase (sucrose) reactions according to the manufacturer's instructions. Absorbance was measured at $340 \mathrm{~nm}$ using the Microplate Reader Spectra (SPECTRA max190, Molecular Devices, San Francisco, CA, USA).

Quantification of extraradical hyphal length density (HLD) and intraradical AM colonization

To determine the development of extraradical mycelium (ERM), $4 \mathrm{~g}$ of air-dried growth substrate collected from both $\mathrm{PC}$ and $\mathrm{HC}$ were blended with $250-\mathrm{ml}$ water, then $5-\mathrm{ml}$ aliquots were filtered through $25-\mathrm{mm}$ membrane filters (1.2- $\mu \mathrm{m}$ pore size) to collect hyphae. Hyphae were stained using trypan blue and hyphal length was measured following the grid line intercept method by observing 25 random fields of view per filter at $\times 200$ magnifications under a microscope (Tennant 1975). Two technical replicates for each sample were performed. Hyphal length density (HLD) was expressed as meters of extraradical mycelium per gram substrate. Intraradical AM fungal colonization was determined according to a modified procedure described by Phillips and Hayman (Phillips and Hayman 1970). Briefly, subsamples of fresh roots were cleared with $10 \% \mathrm{KOH}$ and then stained with trypan blue, omitting phenol from solutions and $\mathrm{HCl}$ from the rinse. Thirty randomly selected $1-\mathrm{cm}$ root segments were examined using the microscope at $\times 200$ magnification according to Trouvelot et al. (1986). 
Plant and fungal gene expression analysis

Total RNA was extracted from root samples using TRIzol (Invitrogen, Carlsbad, CA), according to the manufacturer's instructions, and quantified spectrophotometrically using the NanoDrop device. Complementary DNA (cDNA) was synthesized from the RNA samples using a PrimeScript ${ }^{\circledR}$ RT Reagent Kit (TAKARA Biotechnology Co. Ltd, Dalian, China). Gene transcript levels for each sample were determined in the Bio-Rad iQ5 Optical system (Bio-Rad Laboratories, Hercules, CA) with two technical replicates per reaction. Each $25 \mu$ amplification reaction for real time PCR contained $5 \mu 1$ 1:10-diluted cDNA samples, $500 \mathrm{nM}$ of gene-specific primers (Table 1), and $12.5 \mu \mathrm{l}$ of SYBR Green I PCR Mix (TAKARA Biotechnology Co. Ltd). The PCR program was as follows: $30 \mathrm{~s}$ at $95^{\circ} \mathrm{C}$, followed by 40 cycles at $95^{\circ} \mathrm{C}$ for $5,45 \mathrm{~s}$ at 56 or $57^{\circ} \mathrm{C}$ (Table 1) for annealing, and $72{ }^{\circ} \mathrm{C}$ for $45 \mathrm{~s}$. Expression of all plant and fungal genes were normalized to the corresponding translation elongation factor (MtTEF, GiTEF, separately) using the $2^{-\Delta \Delta \mathrm{Ct}}$ method (Pfaffl 2001).
Statistical analysis

All experimental data are presented as the mean $\pm \mathrm{SD}$ of observations. Two-way ANOVA analyses were performed to examine the effects of night warming and AM fungal inoculation on plant growth and reproduction parameters, mineral nutrient acquisition, sugar assimilation, MtSucS genes expression, and hyphal length density. All variances of the dependent variable were tested for normality. Flower number data were subjected to power transformation to meet normality. Where a significant interaction between night warming and AM fungal inoculation was revealed by ANOVA, multiple comparisons between treatments were performed using the least significant difference (LSD) test at $P<0.05$. If there were no significant interactions, Student's $t$ test was performed to examine the effect of night warming or mycorrhizal colonization, respectively. Student's $t$ test was also adopted to examine the effect of night warming on mycorrhizal colonization and AM symbiosisrelated gene expression. All statistical analyses were carried

Table 1 Summary of primers used in real time PCR experiments

\begin{tabular}{|c|c|c|c|c|}
\hline & Primer name & Primer sequence $\left(5^{\prime}-3^{\prime}\right)$ & Annealing $\left({ }^{\circ} \mathrm{C}\right)$ & Reference \\
\hline \multirow[t]{12}{*}{ Plant genes } & $\begin{array}{l}\text { MtBcp1_F1 } \\
\text { MtBcp1_R1 }\end{array}$ & $\begin{array}{l}\text { CATCTTTGCATGAGAGACTTA } \\
\text { AATGAATGGGAGAGTTACAAT }\end{array}$ & 57 & Baier et al. (2010) \\
\hline & $\begin{array}{l}\text { MtScp1_F1 } \\
\text { MtScp1_R1 }\end{array}$ & $\begin{array}{l}\text { GGTTTCTCTTTATGCTTGTTT } \\
\text { TCAGCTAGTCTTAGCTCCTCT }\end{array}$ & 57 & Baier et al. (2010) \\
\hline & $\begin{array}{l}\text { MtPT4_F1 } \\
\text { MtPT4_R1 }\end{array}$ & $\begin{array}{l}\text { TGAGTTGTTGGTTCTTGTTAG } \\
\text { TATAAAAGAGCGAAGAGGTTT }\end{array}$ & 57 & Baier et al. (2010) \\
\hline & $\begin{array}{l}\text { MtAnn2_F1 } \\
\text { MtAnn2_R1 }\end{array}$ & $\begin{array}{l}\text { GCAAAAGTTACCATGTGATTA } \\
\text { ATTGATTCATGAAGAATGTCA }\end{array}$ & 57 & Baier et al. (2010) \\
\hline & $\begin{array}{l}\text { MtSt1_F1 } \\
\text { MtSt1_R1 }\end{array}$ & $\begin{array}{l}\text { ATTGAAGAGATGGACAGAGTT } \\
\text { AATAATCCCGTAATTTTGAAG }\end{array}$ & 57 & Baier et al. (2010) \\
\hline & $\begin{array}{l}\text { MtCOMT_F1 } \\
\text { MtCOMT_R1 }\end{array}$ & $\begin{array}{l}\text { TATTGTGAGAAATGACGAGAG } \\
\text { CTTTTCACTTAAAGGAGCAAT }\end{array}$ & 57 & Baier et al. (2010) \\
\hline & $\begin{array}{l}\text { MtSucS1_F1 } \\
\text { MtSucS1_R1 }\end{array}$ & $\begin{array}{l}\text { CTTTTGGAATTTCTCAGACTT } \\
\text { GACATCATCTTGAGCAAAGTA }\end{array}$ & 57 & Baier et al. (2010) \\
\hline & $\begin{array}{l}\text { MtSucS2_F1 } \\
\text { MtSucS2_R1 }\end{array}$ & $\begin{array}{l}\text { AAACAAGGACTTGATTTCACT } \\
\text { TCAGGATAACATTGTAACTCG }\end{array}$ & 57 & Baier et al. (2010) \\
\hline & $\begin{array}{l}\text { MtSucS3_F1 } \\
\text { MtSucS3_R1 }\end{array}$ & $\begin{array}{l}\text { ATATGAGCATCTACTTCCCAT } \\
\text { TCTAAGTCTTTGGATTCCTTC }\end{array}$ & 57 & Baier et al. (2010) \\
\hline & $\begin{array}{l}\text { MtSucS4_F1 } \\
\text { MtSucS4_F1 }\end{array}$ & $\begin{array}{l}\text { AAGATACTCTTTCTGCTCACC } \\
\text { GTTCTTCTTTGAAGCTGAGAT }\end{array}$ & 57 & Baier et al. (2010) \\
\hline & $\begin{array}{l}\text { MtSucS5_F1 } \\
\text { MtSucS5_R1 }\end{array}$ & $\begin{array}{l}\text { GTAGTCTCTGGCATCAATGTA } \\
\text { GAAGAATCCTCCAACAATTAC }\end{array}$ & 57 & Baier et al. (2010) \\
\hline & $\begin{array}{l}\text { MtTEF_F1 } \\
\text { MtTEF_R1 }\end{array}$ & $\begin{array}{l}\text { GATTGCCACACCTCTCACAT } \\
\text { TCTTCTCCACAGCCTTGATG }\end{array}$ & 57 & Helber et al. (2011) \\
\hline \multirow[t]{3}{*}{ Fungal genes } & $\begin{array}{l}\text { GiMST2_F1 } \\
\text { GiMST2_R1 }\end{array}$ & $\begin{array}{l}\text { GGCAGGATATTTGTCTGATAG } \\
\text { GCAATAACTCTTCCCGTATAC }\end{array}$ & 56 & Helber et al. (2011) \\
\hline & $\begin{array}{l}\text { GiTEF_F1 } \\
\text { GiTEF_R1 }\end{array}$ & $\begin{array}{l}\text { TGTTGCTTTCGTCCCAATATC } \\
\text { GGTTTATCGGTAGGTCGAG }\end{array}$ & 56 & Helber et al. (2011) \\
\hline & $\begin{array}{l}\text { GiPT_F1 } \\
\text { GiPT_R1 }\end{array}$ & $\begin{array}{l}\text { CGCGTTGGATATTGCTTTTT } \\
\text { GAGGACAGCGAAACCCATTA }\end{array}$ & 56 & Campos-Soriano et al. (2010) \\
\hline
\end{tabular}


out using the SPSS16.0 software package for windows (version 13.0, SPSS Inc, USA).

\section{Results}

\section{Mycorrhizal colonization}

Inoculation with $R$. irregularis resulted in extensive mycorrhizal colonization ( $>60 \%$ ) of the Medicago truncatula roots, while no colonization was detected in the non-inoculated plants (Fig. 1). Night warming significantly increased total root colonization compared with the ambient temperature control $(P<0.05)$, but had no significant effect on arbuscule abundance. HLD both in PC and HC of the inoculated microcosms was much higher than that of non-inoculated controls
$(P<0.01$, Fig. 1). However, night warming showed no significant effects on HLD in either compartment.

Plant biomass and reproductivity

Significant positive interactions between AM inoculation and night warming were recorded for flower number $(P<0.05)$, root dry biomass $(P<0.01)$, and root to shoot ratio $(P<0.05)$ (Table 2). In general, mycorrhizal colonization resulted in more pronounced growth-promoting effects, especially for root growth, under night warming than under ambient temperature.

Night warming significantly reduced plant shoot and root dry weights $(P<0.05)$, plant flower number $(P<0.01)$, and seed number $(P<0.01)$, especially for non-mycorrhizal plants (Table 2). On the other hand, AM fungal colonization significantly increased plant dry weight $(P<0.01)$ and seed number $(P<0.01)$ under both ambient temperature and night warming
Fig. 1 Effect of night warming (AT ambient temperature; $N W$ night warming) and $R$. irregularis inoculation of $M$. truncatula (non-inoculated, white bars; inoculated, black bars) on AM fungal colonization and external hyphal development. Two-way ANOVA was performed for data of hyphal length density, while Student's $t$ test was performed for data of AM fungal colonization. Data are presented as mean \pm standard deviation $(n=4)$. Only significant effects by ANOVA are displayed: $T$, temperature treatment; $M$, mycorrhizal treatment; $\mathrm{T} \times \mathrm{M}$, interaction. ** indicate highly significant effects $(P<0.01)$. Where there were no significant interactions between AM fungal inoculation and night warming, Student's $t$ test $(P<0.05)$ was performed to examine the effects of AM fungal inoculation or night warming respectively: Dollar signs indicate significant differences between inoculated and noninoculated treatments under the same warming condition, while Number sign indicates significant differences between ambient temperature and night warming under the same mycorrhizal status
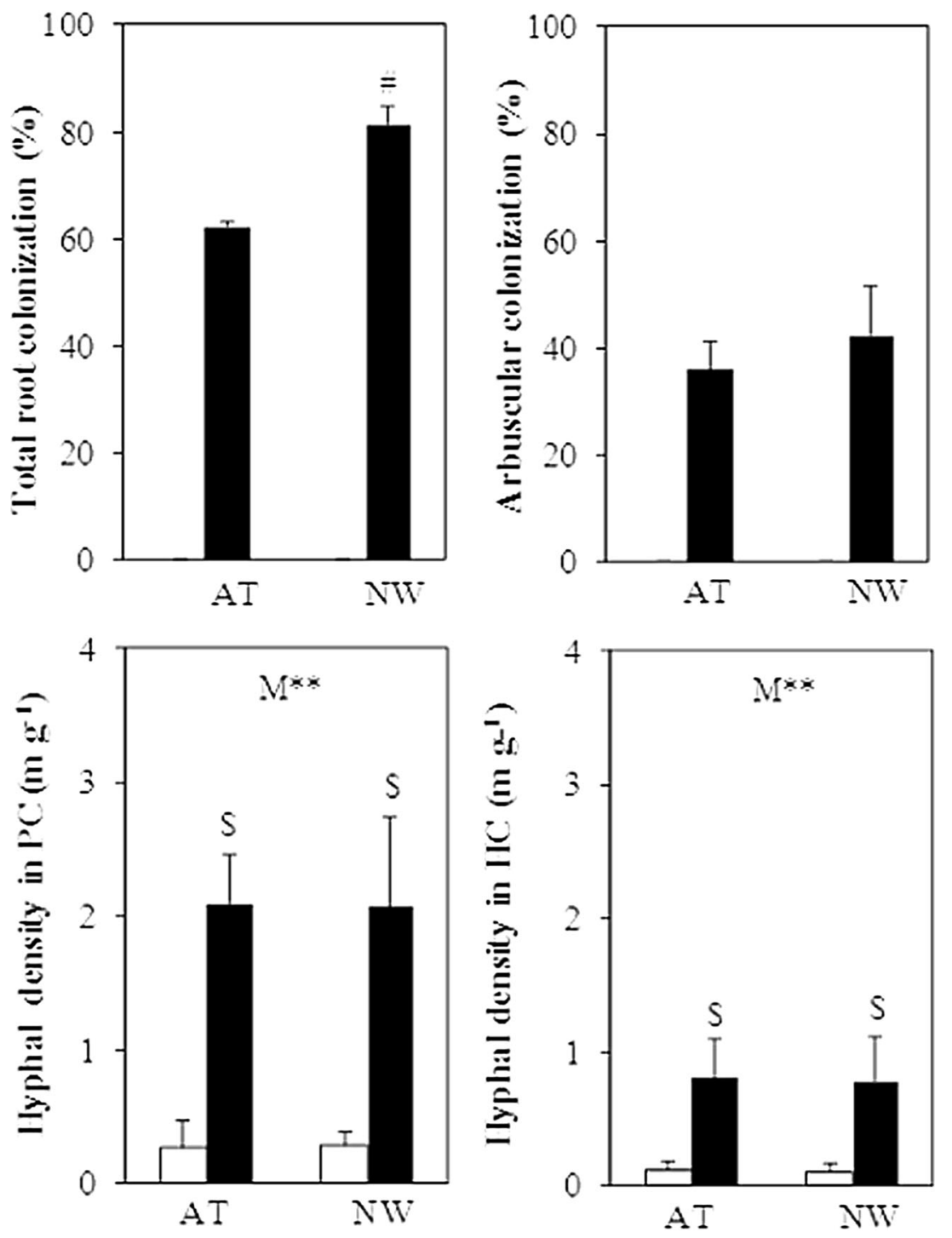
Table 2 Plant growth and reproduction parameters of M. truncatula as influenced by $R$. irregularis inoculation and night warming. Data are presented as mean \pm standard deviation $(n=4)$

\begin{tabular}{|c|c|c|c|c|c|}
\hline & $\begin{array}{l}\text { Flower number } \\
\left(N \operatorname{pot}^{-1}\right)\end{array}$ & $\begin{array}{l}\text { Seed number } \\
\left(N \operatorname{pot}^{-1}\right)\end{array}$ & $\begin{array}{l}\text { Shoot dry weight } \\
\left(\mathrm{g} \mathrm{pot}^{-1}\right)\end{array}$ & $\begin{array}{l}\text { Root dry weight } \\
\left(\text { g pot }^{-1}\right)\end{array}$ & Root/shoot \\
\hline AT & $15.0 \pm 0.82 \mathrm{a}$ & $11.0 \pm 2.16^{\#}$ & $2.76 \pm 0.39^{\#}$ & $0.26 \pm 0.04 \mathrm{~b}$ & $0.10 \pm 0.01 \mathrm{~b}$ \\
\hline MAT & $13.3 \pm 0.50 \mathrm{~b}$ & $17.5 \pm 2.87^{\# \$}$ & $3.46 \pm 0.23^{\$}$ & $0.37 \pm 0.04 \mathrm{a}$ & $0.11 \pm 0.01 \mathrm{~b}$ \\
\hline NW & $9.50 \pm 2.38 \mathrm{c}$ & $6.75 \pm 1.50$ & $1.81 \pm 0.18$ & $0.17 \pm 0.01 \mathrm{c}$ & $0.09 \pm 0.01 \mathrm{~b}$ \\
\hline MNW & $11.5 \pm 1.26 b c$ & $11.5 \pm 3.42^{\$}$ & $3.08 \pm 0.41^{\$}$ & $0.38 \pm 0.04 \mathrm{a}$ & $0.12 \pm 0.01 \mathrm{a}$ \\
\hline \multicolumn{6}{|l|}{ Significance of } \\
\hline AM inoculation & NS & $* *$ & $* *$ & $* *$ & $* *$ \\
\hline Night warming & $* *$ & $* *$ & $* *$ & $*$ & NS \\
\hline Interaction & $*$ & NS & NS & $* *$ & $*$ \\
\hline
\end{tabular}

Multi-comparison was performed across all treatments where significant interactions between AM fungal inoculation and night warming were detected by ANOVA. Different lower case letters followed the data in the same column indicate significant differences between treatments by LSD test $(P<0.05)$. Where there were no significant interactions, Student's $t$ test $(P<0.05)$ was performed to examine the effects of AM fungal inoculation or night warming, respectively.

$A T$ ambient temperature without $R$. irregularis inoculation; MAT ambient temperature with $R$. irregularis inoculation; $N W$ night warming without $R$. irregularis inoculation; $M N W$ night warming with $R$. irregularis inoculation; NS not significant

$* P<0.05, * * P<0.01$, by analysis of variance

$\$$ Significant differences between inoculated and non-inoculated treatments under the same warming condition

${ }^{\text {\# }}$ Significant differences between ambient temperature and night warming under the same mycorrhizal status

conditions, and significantly increased root to shoot ratios under night warming $(P<0.01)$ (Table 2$)$. The overall increases in shoot and root dry weight by mycorrhizal colonization were $43 \%(P<0.01)$ and $76 \%(P<0.01)$, respectively, while seed number increased from 8.9 pot $^{-1}$ for nonmycorrhizal plants to 14.5 pot $^{-1}$ for mycorrhizal plants $(P<0.01)$. However, no significant difference was found in flower number between inoculation treatments.

\section{Mineral nutrient acquisition by M. truncatula}

The effects of AM fungal colonization on $\mathrm{P}, \mathrm{K}, \mathrm{Ca}$, and $\mathrm{Zn}$ concentrations both in shoots and in roots were independent of night warming, as shown by the non-significant interactions between the two treatments.

Night warming significantly reduced shoot $\mathrm{Zn}(P<0.01)$ and root $\mathrm{P}(P<0.01)$ concentrations for mycorrhizal plants only (Fig. 2). AM fungal colonization increased shoot $\mathrm{Zn}$ concentration from 0.035 to $0.055 \mathrm{mg} \mathrm{g}^{-1}(P<0.05)$ and tended to increase root $\mathrm{Zn}$ concentration $(P=0.07)$. No difference in shoot $\mathrm{P}$ concentration was found between $R$. irregularis-inoculated and non-inoculated plants, while root $\mathrm{P}$ concentration in mycorrhizal plants $\left(2.43 \mathrm{mg} \mathrm{g}^{-1}\right)$ was significantly higher $(P<0.01)$ than that in nonmycorrhizal ones $\left(1.91 \mathrm{mg} \mathrm{g}^{-1}\right)$. Root $\mathrm{Ca}$ concentrations of $R$. irregularis-inoculated plants increased by $43 \%(P<0.01)$, while shoot $\mathrm{Ca}$ concentrations decreased by $15 \%(P<0.01)$ compared to those of non-inoculated plants. In contrast, AM fungal colonization did not affect shoot $\mathrm{K}$ concentrations, but decreased root $\mathrm{K}$ concentrations by $15 \%(P<0.05)$.

\section{Sugar assimilation by M. truncatula}

No significant interactions were observed between night warming and AM fungal inoculation on sugar concentrations in different plant parts, except for root sucrose: mycorrhizal colonization decreased root sucrose concentration under night warming $(P<0.05)$ but showed an insignificant effect under ambient temperature.

Night warming significantly reduced concentrations of sucrose, glucose and fructose in plant leaves by 19,35 , and $31 \%$, respectively ( $P<0.05$ in all cases), while $R$. irregularis inoculation did not affect the concentration of any of the analysed sugars in plant leaves (Fig. 3). In contrast, night warming significantly increased sucrose concentration by $30 \%(P<0.05)$ in roots but did not affect glucose or fructose concentrations. On the other hand, AM fungal colonization significantly increased root glucose concentrations by $51 \%$ $(P<0.01)$ but had no effect on root sucrose or fructose concentrations. Neither night warming nor $R$. irregularis inoculation showed significant effects on stem sugar concentrations.

Expression of $\mathrm{MtSucS}$ family genes and AM marker genes

Among the five sucrose synthase genes of the $M t S u c S$ family (MtSucS1, MtSucS2, MtSucS3, MtSucS4, and MtSucS5), 

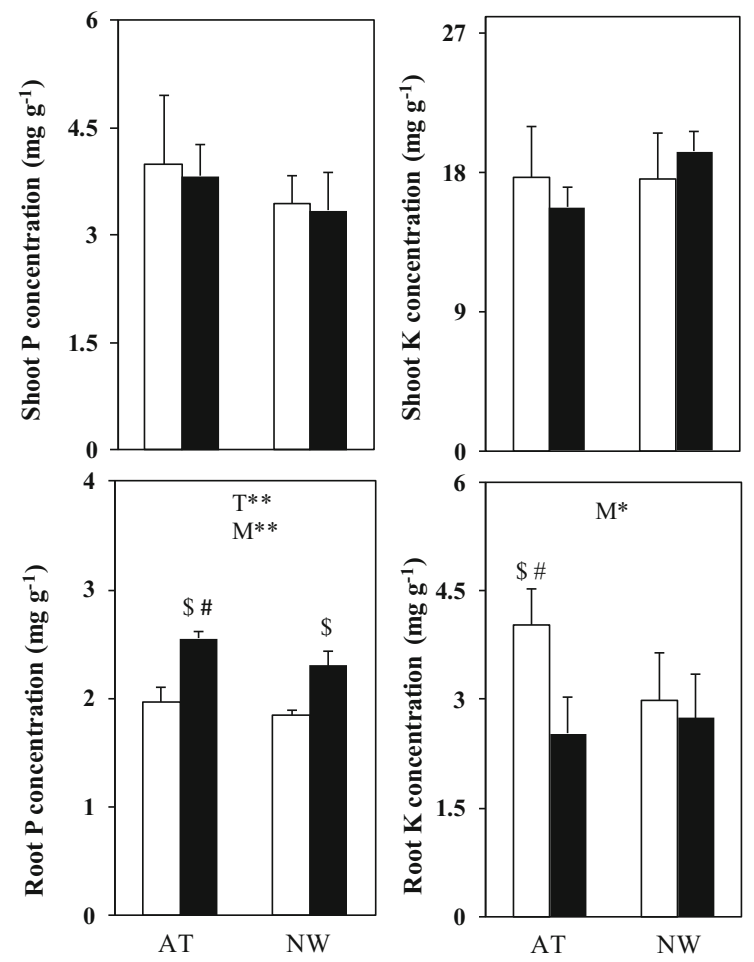

Fig. 2 Effect of night warming ( $A T$, ambient temperature; $N W$, night warming) and $R$. irregularis inoculation (non-inoculated, white bars; inoculated, black bars) on $\mathrm{P}, \mathrm{Zn}, \mathrm{K}$, and $\mathrm{Ca}$ concentrations in shoots and roots of $M$. truncatula. Data are presented as mean \pm standard deviation $(n=4)$ and were analyzed using two-way ANOVA. Only significant effects by ANOVA are displayed: $T$, temperature treatment; $M$, mycorrhizal treatment; $\mathrm{T} \times \mathrm{M}$, interaction. $* *$ indicates highly significant effects $(P<0.01)$, while $*$ indicates significant effects $(P<0.05)$. Where there

MtSucS1 showed highest expression while MtSucS5 exhibited lowest expression in M. truncatula roots (Fig. 4).

There were significant interactions between AM fungal inoculation and night warming on the expression of MtSucS1 $(P<0.01)$, MtSucS4 $(P<0.05)$, and MtSucS5 $(P<0.01)$. In general, mycorrhizal colonization decreased the expression of these genes under night warming. Night warming significantly stimulated the expression of MtSucS1 $(P<0.01), M t S u c S 2$ $(P<0.01)$, MtSucS4 $(P<0.01)$, and MtSucS5 $(P<0.05)$, while only MtSucS2 and MtSucS5 expression were markedly upregulated by $R$. irregularis colonization $(P<0.05)$, especially under ambient temperature. AM fungal colonization showed differential effects on the expression of $\mathrm{MtSucS1}$ and MtSucS4 under different night temperature regimes: it up-regulated $\mathrm{MtSucS1}$ expression under ambient temperature, but down-regulated $M t S u c S 1$ and $\mathrm{MtSucS4}$ expression under night warming. No significant difference in the expression of $M t S u c S 3$ was found among all treatments.

To better characterize the functionality of AM symbiosis, expression of eight symbiosis-related or -induced genes (MtBcp1, MtScp1, MtPT4, MtAnn2, MtSt1, MtCOMT,
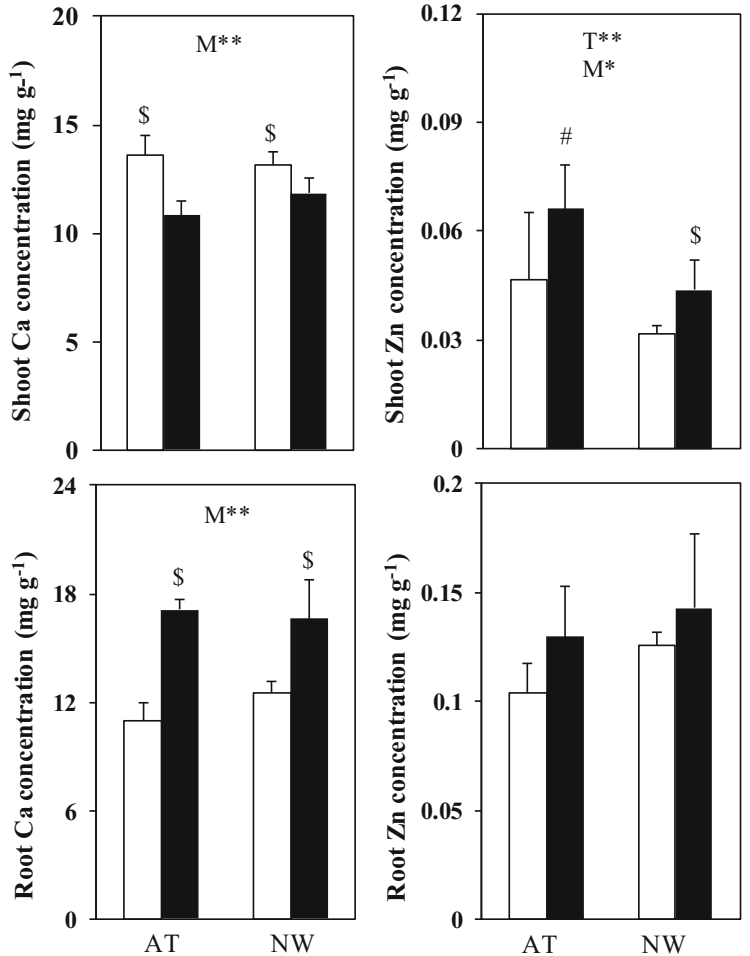

were no significant interactions between AM fungal inoculation and night warming, Student's $t$ test $(P<0.05)$ was performed to examine the effects of AM fungal inoculation or night warming respectively. Dollar signs indicate significant differences between inoculated and non-inoculated treatments under the same warming condition, while number signs indicate significant differences between ambient temperature and night warming under the same mycorrhizal status

GiMST2, GiTEF, and GiPT) was also investigated; no significant difference in the expression of any gene was observed between the experimental treatments (Fig. 5).

\section{Discussion}

In previous studies examining the effects of night warming on plant growth (Wan et al. 2009; Frantz et al. 2004; Clark et al. 2003; Cheesman and Winter 2013), both negative effects of night warming on tropical tree performance (Clark et al. 2003) and positive effects of elevated night temperature on seedlings of two neo-tropical tree species (Cheesman and Winter 2013) have been reported. In the present study, night warming significantly suppressed the growth and development of M. truncatula. The different responses of plant growth to night warming could be explained by different plant resilience or life-history strategies (Price and Waser 1998; Root et al. 2003). Despite this, no study has, so far, considered the potential influence of plant symbiotic status on plant performance under night warming. Here, it is clearly demonstrated 

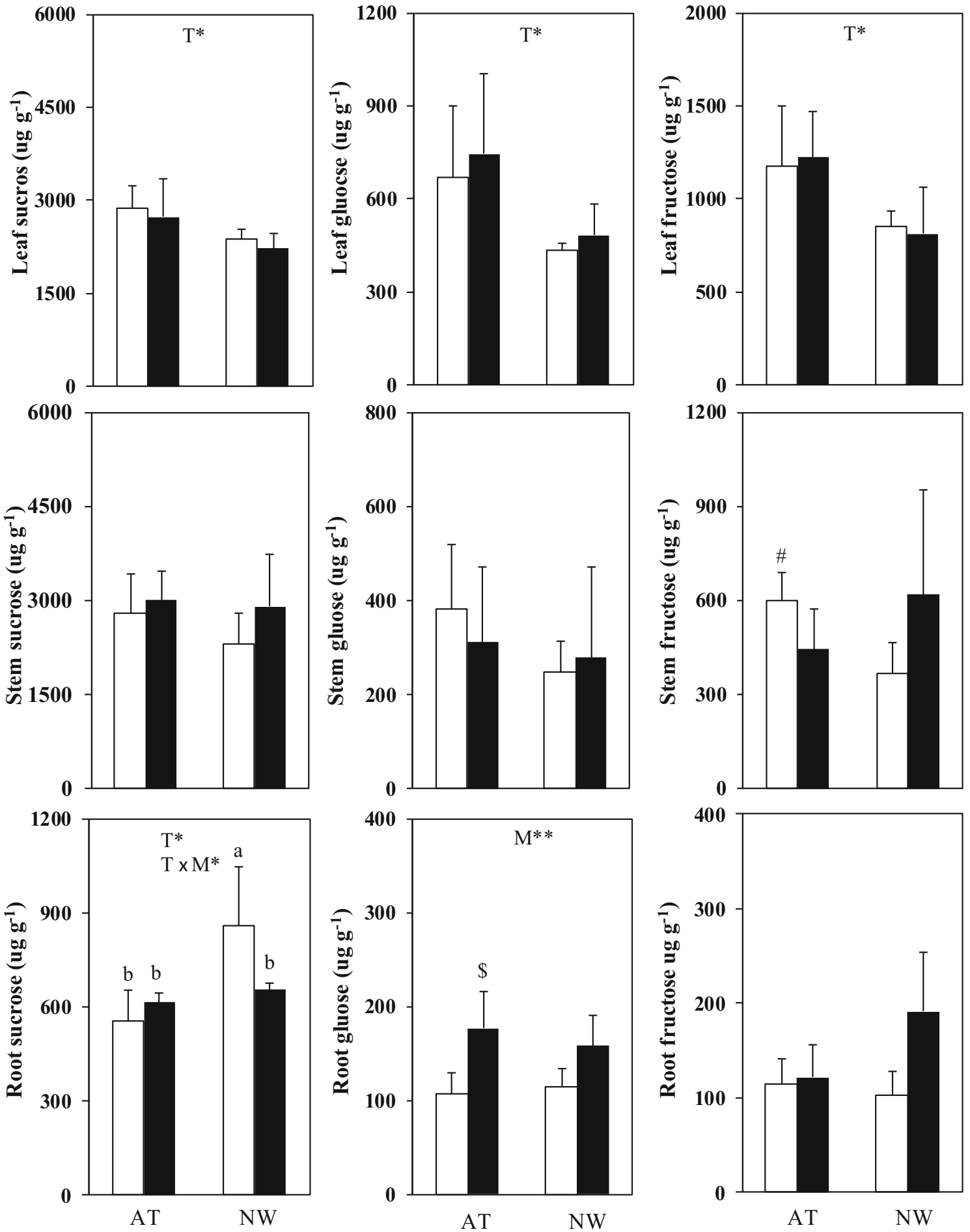

Fig. 3 Effects of night warming ( $A T$ ambient temperature; $N W$ night warming) and $R$. irregularis inoculation (non-inoculated, white bars; inoculated, black bars) on the sugar concentration in different tissues of $M$. truncatula. Data are presented as mean \pm standard deviation $(n=4)$ and were analyzed by two-way ANOVA. Only significant effects by ANOVA are displayed: $T$, temperature treatment; $M$, mycorrhizal treatment; $\mathrm{T} \times \mathrm{M}$, interaction. $* *$ indicates highly significant effects $(P<0.01)$, while * indicates significant effects $(P<0.05)$. Multi-comparison was performed across all treatments where significant interactions between AM fungal inoculation and night warming were detected by ANOVA. Different lower case letters followed the data in the same column indicate significant differences between treatments by LSD test $(P<0.05)$. Where there were no significant interactions, Student's $t$ test $(P<0.05)$ was performed to examine the effects of AM fungal inoculation or night warming respectively. Dollar sign indicates significant differences between inoculated and non-inoculated treatments under the same warming condition, while number sign indicates significant differences between ambient temperature and night warming under the same mycorrhizal status 

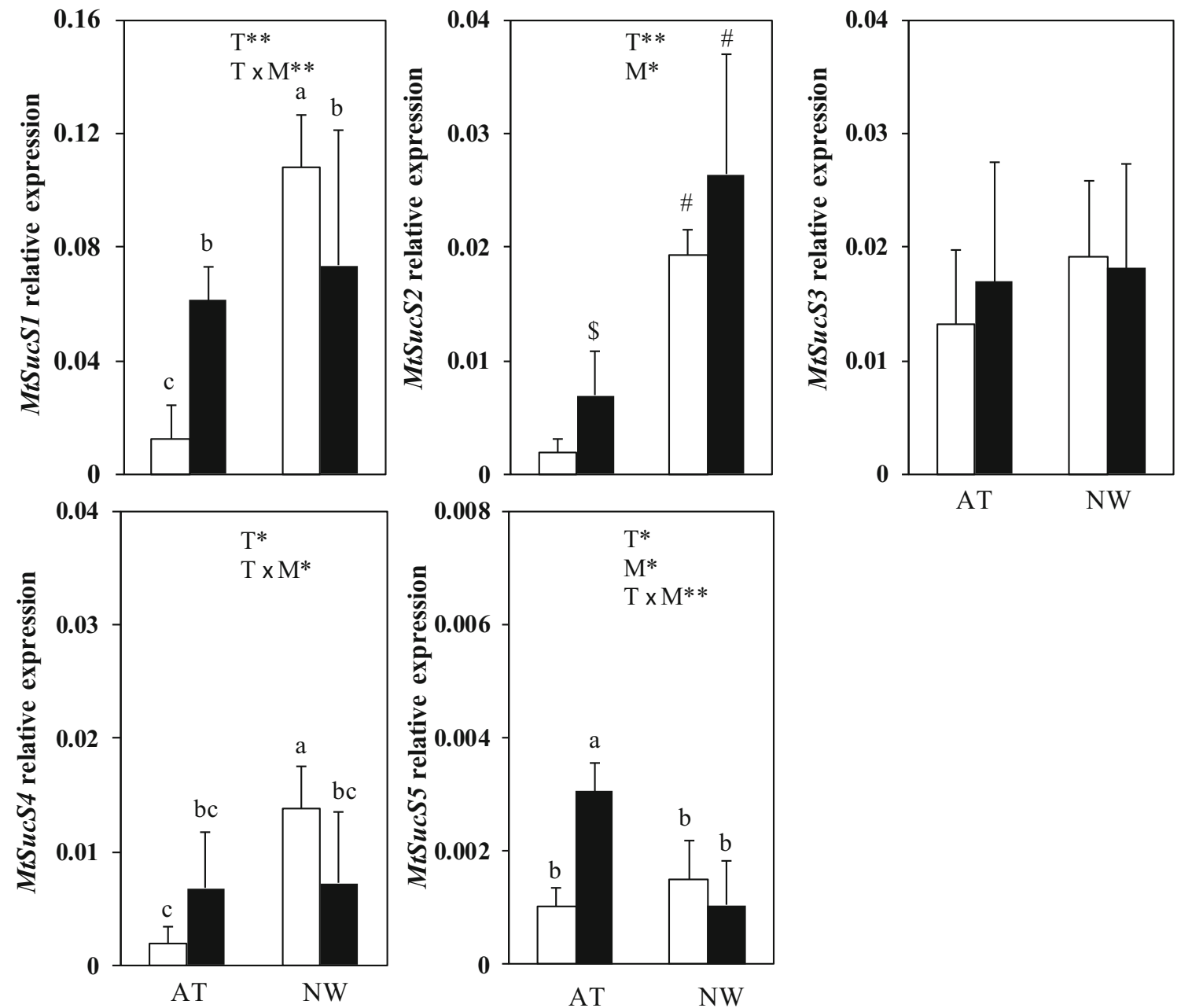

Fig. 4 Effects of night warming ( $A T$, ambient temperature; $N W$, night warming) and $R$. irregularis inoculation (non-inoculated, white bars; inoculated, black bars) on transcript accumulation of five MtSucS genes in $M$. truncatula revealed by real time RT-PCR. The relative quantitation was normalized against the constitutively expressed control gene MtTEF. Data are presented as mean \pm standard deviation $(n=4)$ and were analyzed by two-way ANOVA. Only significant effects by ANOVA are displayed: $T$, temperature treatment; $M$, mycorrhizal treatment; $\mathrm{T} \times \mathrm{M}$, interaction. ** indicates highly significant effects $(P<0.01)$, while * indicates significant effects $(P<0.05)$. Multi-comparison was performed across all treatments

where significant interactions between AM fungal inoculation and night warming were detected by ANOVA. Different lower case letters followed the data in the same column indicate significant differences between treatments by LSD test $(P<0.05)$. Where there were no significant interactions, Student's $t$ test $(P<0.05)$ was performed to examine the effects of AM fungal inoculation or night warming respectively. Dollar signs indicates significant differences between inoculated and non-inoculated treatments under the same warming condition, while number signs indicate significant differences between ambient temperature and night warming under the same mycorrhizal status

that AM symbiosis can substantially mitigate negative effects of night warming on plant growth: night warming negatively affected non-mycorrhizal $M$. truncatula, but showed no significant effects on mycorrhizal plants. This provides strong support to our hypothesis that AM fungi could play important roles in plant resilience under the climate change scenario of night warming. Moreover, $R$. irregularis exhibited a more pronounced influence on root than on shoot growth of M. truncatula. A possible explanation is that AM fungi can directly influence root initiation and branching (eg AzcónAguilar et al. 1996).

Night warming potentially has negative effects on plant reproduction (Hedhly et al. 2009; Grant et al. 2011). A previous study demonstrated that rice yields declined with higher

night temperatures and grain yield decreased by $10 \%$ for every $1{ }^{\circ} \mathrm{C}$ increase at night during the dry season (Peng et al. 2004). A significant negative effect of night warming on both seed and flower number was similarly recorded in the present study on $M$. truncatula. One reason for decreased seed number could be that reproductive physiology might be vulnerable to temperature changes. Another possibility is that night warming indirectly reinforces the susceptibility of reproduction by affecting other physiological processes, such as plant nutrient acquisition (Hedhly et al. 2009). Karasawa et al. (2012) showed that a small reduction in soil temperature $\left(2.7^{\circ} \mathrm{C}\right)$ suppressed plant nutrition acquisition, including root $\mathrm{N}, \mathrm{K}$, and, in particular, $\mathrm{P}$ and $\mathrm{Zn}$. The small constant increased temperature $\left(1.53{ }^{\circ} \mathrm{C}\right)$ during night time had a 


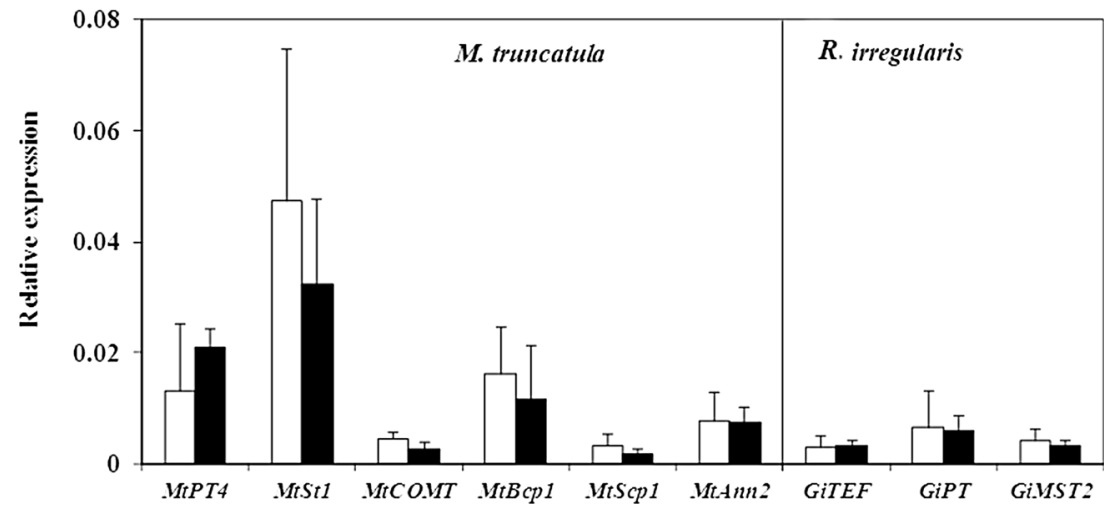

Fig. 5 Transcript accumulation of symbiosis-related genes in mycorrhizal roots of $M$. truncatula under different treatments as revealed by real time RT-PCR. Open columns stand for control (ambient temperature), while filled columns stand for night warming. The relative quantitation of all $M$. truncatula genes was normalized against the constitutively expressed control gene MtTEF. Expression of GiTEF, which represents the abundance of $R$. irregularis in roots, was normalized against MtTEF, while GiPT and GiMST2 were normalized against the constitutively expressed control gene GiTEF. Data are presented as mean \pm standard deviation $(n=4)$ and analyzed by Student's $t$ test. No significant differences between treatments were detected for all assayed genes negative effect on $M$. truncatula $\mathrm{P}$ and $\mathrm{Zn}$ uptake. Consequently, plant nutrition acquisition could be very sensitive to temperature changes including environmental warming and cooling. It is well known that $\mathrm{Zn}$ is a critical micronutrient for plant reproduction, acting as the key enzyme cofactor to regulate microsporogenesis and pollen fertility (Pandey et al. 2006). Zn deficiency has been reported to result in decreased seed yield of wheat (Cakmak et al. 1996) and maize (Sharma et al. 1990). In the present study, night warming significantly decreased $\mathrm{Zn}$ concentrations in plant shoots, but $R$. irregularis enhanced plant $\mathrm{Zn}$ uptake under night warming. A recent meta-analysis of AM fungal functions in crop $\mathrm{Zn}$ nutrition also supports an important role of AM fungi in $\mathrm{Zn}$ nutrition under distinct environmental conditions (Lehmann et al. 2014). Therefore, the extent to which climatic changes affect plant physiology, especially nutrition acquisition, could be modified by the plant symbiotic status.

Considering that both AM fungi and night warming could influence plant sugar metabolism, glucose, fructose, and sucrose were determined in M. truncatula leaves, stems, and roots. In consistence with previous studies (Turnbull et al. 2002; Wan et al. 2009), a significant decrease in sugar concentrations in leaves was observed under night warming. Interestingly, all sugar concentrations in the roots did not decrease, and the sucrose concentration even increased under night warming. This suggests that night warming was likely to influence sugar translocation from the autotrophic leaf source to the heterotrophic root sink via phloem. This phenomenon could involve a plant carbohydrate source-sink relationship, as the carbohydrate allocation from source to various sinks is usually controlled both by sink demand and source photosynthate production (Farrar and Jones 2000). Night warming enhances night respiration (Wan et al. 2009), which could result in higher carbon substrate demand in the roots.
Therefore, increased sucrose in the root may be a compensation for the intensive night respiration.

Plant sucrose synthase (SusS) family genes are considered to encode key enzymes involved in carbon metabolism (Huber and Akazawa 1986). They catalyze a reversible reaction of sucrose synthesis and hydrolysis, and sucrose hydrolysis is predominantly detected in sink tissues such as roots (Sturm and Tang 1999). In parallel with the increased sucrose in $M$. truncatula roots, night warming significantly enhanced the expression of four out of five $S u c S$ genes. This suggests that sucrose induced $S u c S$ gene expression, which subsequently produced more monosaccharide for sustaining intensive root respiration under night warming. In mycorrhizal plants, sucrose is usually hydrolyzed to monosaccharide by sucrose synthase (SucS) or invertase (Baier et al. 2010) prior to utilization by AM fungi. Indeed, AM fungal colonization has been previously shown to induce expression of the SucS gene, MtSucS1 (Hohnjec et al. 2003). Upregulation of MtSucS1 by $R$. irregularis colonization similarly occurred under ambient temperature in the present study. However, lower MtSucS1 expression was found in the mycorrhizal plants under night warming. A possible reason could be that the AM association consumed more sucrose under night warming and the resulting decrease in sucrose in roots ultimately led to lower MtSucS1 expression (Hawkes et al. 2008). Additionally, MtSucS1 expression correlated with $M$. truncatula root sucrose concentration, irrespective of the experimental treatments, which again, suggests sucrose regulated $\mathrm{MtSucS1}$ expression. Although the function of the other SucS genes has so far not been identified, the induced expression of these genes, such as MtSucS2 and MtSucS5, by night warming and AM fungal inoculation at least suggests their potential influence on sucrose metabolism. 
Previous studies have demonstrated that soil warming could affect both AM fungal colonization and ERM development (Rillig et al. 2002; Heinemeyer et al. 2006; Karasawa et al. 2012). Increases in soil temperature led to increased entry points on roots, suggesting that root colonization could be stimulated by greater net leakage of root metabolites under warming conditions (Smith and Bowen 1979). However, results from different studies are not always consistent. For example, soil warming promoted ERM development in a fungal pot compartment, but had no effect on colonization and even decreased vesicle frequency (Hawkes et al. 2008), while warming by infrared radiators in field plots stimulated both AM fungal colonization and ERM growth (Rillig et al. 2002). These inconsistent results suggest that the AM fungal colonization does not necessarily correlate with ERM development. In fact, night warming stimulated $R$. irregularis colonization of $M$. truncatula roots in the present study, but it had no significant influence on the other AM fungal parameters, such as HLD and arbuscule abundance. Likewise, expression of selected symbiosis-specific genes (e.g., MtPT4, MtST1, MtCOM1, GiMST2, GiPT) was not correlated with increased AM fungal colonization under night warming. Such findings are partially supported by the report by Isayenkov et al. (2004) that expression of symbiosis-specific genes is tightly linked with arbuscule formation rather than total root colonization. Furthermore, the present results suggest that the functional activity of AM symbiosis may not simultaneously increase with mycorrhizal colonization. However, expression of symbiosis-specific genes could be dynamic during mycorrhizal colonization. These genes have been shown to be induced at early stages of symbiosis establishment, while their expression becomes stable at late stages of mycorrhization (Liu et al. 2003). Therefore, the present results might be reliable as expressions of the symbiosis-specific genes were assessed at the late mycorrhization stage.

In conclusion, the observations from the present study support the hypothesis that AM symbiosis could mitigate negative effects of night warming on plant growth and physiological traits. Meanwhile, night warming generally had little effect on AM establishment and development. Although several studies have reported the mycorrhizal symbiosis to enhance plant resistance to climatic changes (Martin and Stutz 2004; Karasawa et al. 2012), this is the first to demonstrate the involvement of an AM fungus in plant resilience to night warming. Nevertheless, it should be recognized that night temperature increases under glasshouse conditions using infrared radiators may not exactly simulate natural night warming. Environment-controlled growth chambers could provide more accurate temperature warming, and should be considered in future studies. Considering the complexity of a natural ecosystem, it is also of critical importance to perform long-term field experiments (cf. Zhang et al.
2011) to assess the ecological importance of AM fungi under climate changes.

Acknowledgments The study was financially supported by Chinese Academy of Sciences (KZCX2-YW-BR-17; XDB15030100) and National Natural Science Foundation of China (41071178, 41371264 and 31070476).

\section{References}

Alward RD, Detling JK, Milchunas DG (1999) Grassland vegetation changes and nocturnal global warming. Science 283:229-231

Augé RM (2001) Water relations, drought and vesicular-arbuscular mycorrhizal symbiosis. Mycorrhiza 11:361-365

Azcón-Aguilar C, Padilla IG, Encina CL et al (1996) Arbuscular mycorrhizal inoculation enhances plant growth and changes root system morphology in micropropagated Annona cherimola Mill. Agronomie 16(10):647-652

Bai WM, Xia JY, Wan SQ, Zhang WH, Li LH (2012) Day and night warming have different effect on root lifespan. Biogeosciences 9: 375-384

Baier MC, Keck M, Gödde V, Niehaus K, Küster H et al (2010) Knockdown of the symbiotic sucrose synthase MtSucS1 affects arbuscule maturation and maintenance in mycorrhizal roots of Medicago truncatula. Plant Physiol 152:1000-1014

Bond-Lamberty B, Thomson A (2010) Temperature-associated increases in the global soil respiration record. Nature 464:579-582

Cakmak I, Yilmaz A, Kalayci M, Ekiz H, Torun B et al (1996) Zinc deficiency as a critical problem in wheat production in Central Anatolia. Plant Soil 180:165-172

Campos-Soriano L, García-Garrido JM, Segundo BS (2010) Activation of basal defense mechanisms of rice plants by Glomus intraradices does not affect the arbuscular mycorrhizal symbiosis. New Phytol 188:597-614

Cheesman AW, Winter K (2013) Elevated night-time temperatures increase growth in seedlings of two tropical pioneer tree species. New Phytol 197:1185-1192

Clark DA, Piper SC, Keeling CD, Clark DB (2003) Tropical rain forest tree growth and atmospheric carbon dynamics linked to interannual temperature variation during 1984-2000. Proc Natl Acad Sci U S A 100:5852-5857

Farrar JF, Jones DL (2000) The control of carbon acquisition by roots. New Phytol 147:43-53

Frantz JM, Cometti NN, Bugbee B (2004) Night temperature has a minimal effect on respiration and growth in rapidly growing plants. Ann Bot 94:155-166

Grant RF, Kimball BA, Conley MM, White JW, Wall GW et al (2011) Controlled warming effects on wheat growth and yield: field measurements and modeling. Agron J 103:1742-1754

Hawkes CV, Hartley IP, Ineson P, Fitter AH (2008) Soil temperature affects carbon allocation within arbuscular mycorrhizal networks and carbon transport from plant to fungus. Glob Chang Biol 14: $1181-1190$

Hedhly A, Hormaza JI, Herrero M (2009) Global warming and sexual plant reproduction. Trends Plant Sci 14:30-36

Heinemeyer A, Ineson P, Ostle N, Fitter AH (2006) Respiration of the external mycelium in the arbuscular mycorrhizal symbiosis shows strong dependence on recent photosynthates and acclimation to temperature. New Phytol 171:159-170

Helber N, Wippel K, Sauer N, Schaarschmidt S, Hause B et al (2011) A versatile monosaccharide transporter that operates in the arbuscular 
mycorrhizal fungus Glomus sp. is crucial for the symbiotic relationship with plants. Plant Cell 23:3812-3823

Hohnjec N, Perlick AM, Pühler A, Küster H (2003) The Medicago truncatula sucrose synthase gene MtSucS1 is activated both in the infected region of root nodules and in the cortex of roots colonized by arbuscular mycorrhizal fungi. Mol Plant Microbe Interact 16: 903-915

Hood TM, Mills HA (1994) Root-zone temperature affects nutrient uptake and growth of snapdragon. J Plant Nutr 17:279-291

Hu Y, Rillig MC, Xiang D, Hao Z, Chen B (2013) Changes of AM fungal abundance along environmental gradients in the arid and semi-arid grasslands of northern China. PLoS One 8:e57593

Huber SC, Akazawa T (1986) A novel sucrose synthase pathway for sucrose degradation in cultured sycamore cells. Plant Physiol 81: $1008-1013$

Isayenkov S, Fester T, Hause B (2004) Rapid determination of fungal colonization and arbuscule formation in roots of Medicago truncatula using real-time (RT) PCR. J Plant Physiol 161(12): 1379-1383

Javot H, Penmetsa RV, Terzaghi N et al (2007) A Medicago truncatula phosphate transporter indispensable for the arbuscular mycorrhizal symbiosis. Proc Natl Acad Sci U S A 104(5):1720-1725

Karasawa T, Hodge A, Fitter AH (2012) Growth, respiration and nutrient acquisition by the arbuscular mycorrhizal fungus Glomus mosseae and its host plant Plantago lanceolata in cooled soil. Plant Cell Environ 35:819-828

Kaschuk G, Kuyper TW, Leffelaar PA, Hungria M, Giller KE (2009) Are the rates of photosynthesis stimulated by the carbon sink strength of rhizobial and arbuscular mycorrhizal symbioses? Soil Biol Biochem 41:1233-1244

Kimball BA (2005) Theory and performance of an infrared heater for ecosystem warming. Glob Chang Biol 11(11):2041-2056

Lehmann A, Veresoglou SD, Leifheit EF, Rillig MC (2014) Arbuscular mycorrhizal influence on zinc nutrition in crop plants-A metaanalysis. Soil Biol Biochem 69:123-131

Li T, Hu YJ, Hao ZP, Li H, Wang YS, Chen BD (2013) First cloning and characterization of two functional aquaporin genes from an arbuscular mycorrhizal fungus Glomus intraradices. New Phytol 197:617-630

Liu J, Blaylock LA, Endre G et al (2003) Transcript profiling coupled with spatial expression analyses reveals genes involved in distinct developmental stages of an arbuscular mycorrhizal symbiosis. Plant Cell 15(9):2106-2123

Luo Y (2007) Terrestrial carbon-cycle feedback to climate warming. Ann Rev Ecol Evol Syst 38:683-712

Martin CA, Stutz JC (2004) Interactive effects of temperature and arbuscular mycorrhizal fungi on growth, $\mathrm{P}$ uptake and root respiration of Capsicum annuum L. Mycorrhiza 14:241-244

McDonald GK, Paulsen GM (1997) High temperature effects on photosynthesis and water relations of grain legumes. Plant Soil 196(1): $47-58$

Pachauri RK, Reisinger A (2007) Climate Change 2007: Synthesis report. Contribution of working groups I, II and III to the fourth assessment report of the intergovernmental panel on climate change, Intergovernmental Panel on Climate Change. Cambridge University Press, New York
Pandey N, Pathak GC, Sharma CP (2006) Zinc is critically required for pollen function and fertilisation in lentil. J Trace Elem Med Biol 20: 89-96

Peng S, Huang J, Sheehy JE, Laza RC, Visperas RM et al (2004) Rice yields decline with higher night temperature from global warming. Proc Natl Acad Sci U S A 101:9971-9975

Pfaffl MW (2001) A new mathematical model for relative quantification in real-time RT-PCR. Nucleic Acids Res 29:45-45

Phillips JM, Hayman DS (1970) Improved procedures for clearing roots and staining parasitic and vesicular-arbuscular mycorrhizal fungi for rapid assessment of infection. Trans Br Mycol Soc 55:158-161

Pozo MJ, Azcòn-Aguilar C (2007) Unraveling mycorrhiza-induced resistance. Curr Opin Plant Biol 10:393-398

Price MV, Waser NM (1998) Effects of experimental warming on plant reproductive phenology in a subalpine meadow. Ecology 79:12611271

Rillig MC, Wright SF, Shaw MR, Field CB (2002) Artificial climate warming positively affects arbuscular mycorrhizae but decreases soil aggregate water stability in an annual grassland. Oikos 97:5258

Root TL, Price JT, Hall KR, Schneider SH, Rosenzweig C et al (2003) Fingerprints of global warming on wild animals and plants. Nature 421:57-60

Sharma PN, Chatterjee C, Agarwala SC, Sharma CP (1990) Zinc deficiency and pollen fertility in maize (Zea mays). Plant Soil 124:221225

Smith SE, Bowen GD (1979) Soil temperature, mycorrhizal infection and nodulation of Medicago truncatula and Trifolium subterraneum. Soil Biol Biochem 11(5):469-473

Smith SE, Read DJ (2008) Mycorrhizal symbiosis. Academic press, London

Sturm A, Tang GQ (1999) The sucrose-cleaving enzymes of plants are crucial for development, growth and carbon partitioning. Trends Plant Sci 4(10):401-407

Tennant D (1975) A test of a modified line intersect method of estimating root length. J Ecol 63:995-1001

Tindall JA, Mills HA, Radcliffe DE (1990) The effect of root zone temperature on nutrient uptake of tomato. J Plant Nutr 13:939-956

Tommerup IC (1983) Spore dormancy in vesicular-arbuscular mycorrhizal fungi. Trans Br Mycol Soc 81:37-45

Trouvelot A, Kough JL, Gianinazzi-Pearson V (1986) Mesure du taux de mycorhization VA d'un système radiculaire. Recherche de méthodes d'estimation ayant une signification fonctionnelle. In: GianinazziPearson V, Gianinazzi S (eds) physiologie et génétique. 1er Séminaire Dijon, INRA, Paris. pp 217-221

Turnbull MH, Murthy R, Griffin KL (2002) The relative impacts of daytime and night-time warming on photosynthetic capacity in Populus deltoides. Plant Cell Environ 25:1729-1737

Wan S, Xia J, Liu W, Niu S (2009) Photosynthetic overcompensation under nocturnal warming enhances grassland carbon sequestration. Ecology 90:2700-2710

Zhang N, Xia J, Yu X, Ma K, Wan S (2011) Soil microbial community changes and their linkages with ecosystem carbon exchange under asymmetrically diurnal warming. Soil Biol Biochem 43: 2053-2059 